\title{
A Critical Analysis of the Assessment for Micro-teaching Program for English Language Teachers in the Secondary Education in Mainland China*
}

\author{
Jing Shi \\ School of English for International Business, Guangdong University of Foreign Studies, Guangzhou, Guangdong, China
}

\begin{abstract}
Significant effort has been made to support pre-service and novice teacher learning abroad; however, not enough attention has been paid to promoting pre-service and novice teacher learning via collaboration with peer teachers and more expert educators at secondary education level in the context of mainland China. In order to facilitate this type of teacher collaboration and provide necessary support for pre-service and novice English language teachers in high schools in the southern part of China, a micro-teaching program has been incorporated into the pre-service training for these novice teachers. The micro-teaching program aims at equipping novice teachers with relevant teaching skills and behaviors through practice of teaching under controlled conditions. The purpose of this paper is to trace the developmental trajectories of the novice teachers participating in this program and examine the effect of formal assessment on the development of novice teachers. This study reveals that the program can help teachers share teaching strategies and solve practical problems in teaching, thus novice teachers acquire teaching skills and gain confidence in teaching. It is recommended the faculty should incorporate the program not only in pre-training service for novice teachers but also in service for teachers to improve their teaching routine.
\end{abstract}

Index Terms - micro-teaching, pre-service teacher training, assessment and evaluation

\section{INTRODUCTION}

Micro-teaching, a tool for use in teacher training (Allen and Eve, 1968) is defined as "a system of controlled practice that makes it possible to concentrate on specified teaching behavior and to practice teaching under controlled conditions" (Arsal, 2014). Novice teachers have many opportunities to practice their teaching skills step by step in a controlled environment without putting students' learning at risk. Mentor is a facilitator, with novice teachers working collaboratively, in order to practice teaching skills which include: lead-in skills, presenting skills, question-proposing skills, and using reinforcement skills etc. Micro-teaching came into existence in 1960s as a result of educational reform. An unprecedented course focusing on the training of teaching skills was launched for novice teachers in Standford University, which is the prototype of micro-teaching. Micro-teaching aims at analyzing complicated teaching procedures and diversifying the teaching process into small steps. Micro-teaching is deemed as the most effective mode for novice teacher training because of its theoretical base. It is completely different from the "stimulus-reaction " mode based on behaviorism. Micro-teaching is based on the "assimilation-adaption" type, meta-cognition theory, and the manner of "plan-monitor-feedback-washback" . Micro-teaching has been brought into China in 1980s. At the initial stage, it was regarded as the replacement for the old style of teacher training. In accordance with the requirement of the teaching reform, Beijing College of Education has listed ten vital teaching skills for teachers in mainland China, which is the basis for the training for novice teachers. Later, scholars from mainland China have participated in the research of micro-teaching organized by the UNESCO. The effectiveness of micro-teaching has been proved from the perspective of educational theory and psychology, and micro-teaching equipment has been installed in many normal universities afterwards. Micro-teaching, as a new method of training novice teachers, has found its way into mainland China. A majority of the high-school English teachers in mainland China are English major graduates and they have not received any training concerning teaching skills before they become language teachers. Micro-teaching can, technically speaking, equip them with sufficient teaching skills.

\section{THEORETICAL FRAMEWORK}

Researchers have suggested and proved the benefits of micro-teaching for novice teachers as micro-teaching provides novice teachers opportunities to analyze their teaching procedures and reflect on their teaching experiences via

\footnotetext{
* This essay is sponsored by the research project "Micro-teaching for Trainee Teachers in Secondary Education" (Project Code: JCJYB2018009), supported by Guangdong University of Foreign Studies.
} 
engaging them in demonstrations and dialogues. Novice teachers increase feelings of self-awareness and build up confidence which has a positive impact on developing teacher identity and self-efficacy. (Cousine et al.,1978; Fisher \& Frey, 2019; Griffiths, 2016; Merghler \& Tangen, 2010; Donnelly \& Fitzmaurice, 2011)

Traditionally, before novice teachers start their teaching career, they usually are required to go through the class observation by experienced teachers and making changes in accordance with the feedback from senior teachers. The first problem with the conventional method is that it is rather challenging for observer to attend to every details of the situations happening in class. Even if the observer can pay attention to the details of the teaching, he can only focus on what he perceives. The feedback from the experienced teacher to the novice teacher usually include "You only called on students in the front," "Not all the students are engaged, especially the ones at the back," or "The gestures you used cannot make you understood by students. "When the novice teacher receives these feedbacks, he or she might not be able to remember the situation well enough to reflect on his or her performance. Or the teacher might remember it differently or have different perspectives. The second problem with the traditional method is that observers tend to focus more on the teacher: how he or she teaches; rather than the students: how they learn. Too often, the observer is too busy attending to what the teacher is doing, documenting what the teacher is saying during the entire observation. Little attention is paid to the effectiveness of students' learning. (Carver \& Wallace, 1975; kablan, 2012; Phillips, 1975; Bell, 2007)

In the well-equipped micro-teaching laboratory, short segments of a teacher's practice are captured and analyzed from different perspectives. Meanwhile, learners' movements and reactions are also recorded. The limitations of traditional training for novice teachers can be got past by the advantages of micro-teaching.

Despite the advantages of micro-teaching, some experts often challenge the authenticity of it. In this research, novice teachers are required to bring the real problems with them: the lesson study and micro-teaching are combined and the synthesis of them can offer novice teachers opportunities to solve the real problems in the classroom. The type of micro-teaching used in this research, where novice teachers plan the teach their "lessons" to their colleagues at high school. However, there is an understandable question mark over how "authentic" the teaching is this does not necessarily mean that it cannot be a useful and beneficial tool for novice teacher to equip themselves with teaching skills. The teaching process has been decomposed into small parts and novice teachers are required to practice their teaching skills step by step. They bring into the classroom real teaching tasks and their problems and concerns about their teaching routines. (Lee \& Cheng-Chih, 2006; Sachs, 1999; Yogi, 2013)

\section{INTRODUCTION TO THE PROGRAM}

The research is conducted at an affiliated high school of a prestigious university which is renowned for its excellence in language teaching and learning. The micro-teaching laboratory (see picture 1) was established in October 2012 by the university, which was fully-equipped with the multi-functional recording appliances and other relevant electronic appliances. In order to well-prepare the novice teachers of the high school, the micro-teaching training is carried out at the micro-teaching laboratory of the university. The training course consists of six sessions. The trainer illustrates teaching skills and the novice teachers can practice the acquired teaching skills in a controlled environment. The novice teachers observe the trainers' presentation of teachings skills; then they practice the targeted skills and the whole process is recorded. After that, their performance is analyzed and assessed; and finally they re-present the targeted skills.

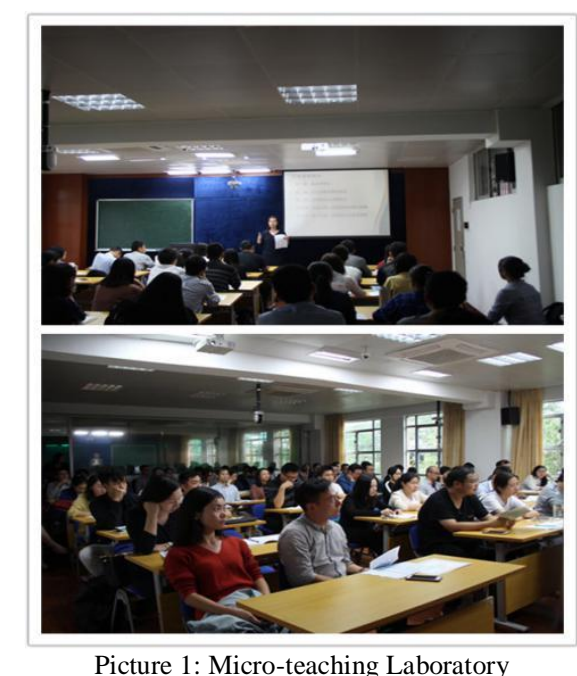

The researcher, also the mentor of the course, based on her teaching experience at the university for sixteen years and the guidance from the books published by $\mathrm{Li}(2009), \mathrm{Li}(2012)$ and Fan \& Gao(2010); journal articles from Liu \& 
An(2005) and Tian(2003), has decided to focus on the following teaching skills: lead-in, illustration and presentation, question-asking, feedback and reinforcement, and wrap-up. The training process for each session includes: preparation of both the mentor and novice teachers beforehand, teaching tasks accomplished by novice teachers during the training session, and assignments for novice teachers after the training session. The training process is illustrated in picture 2.

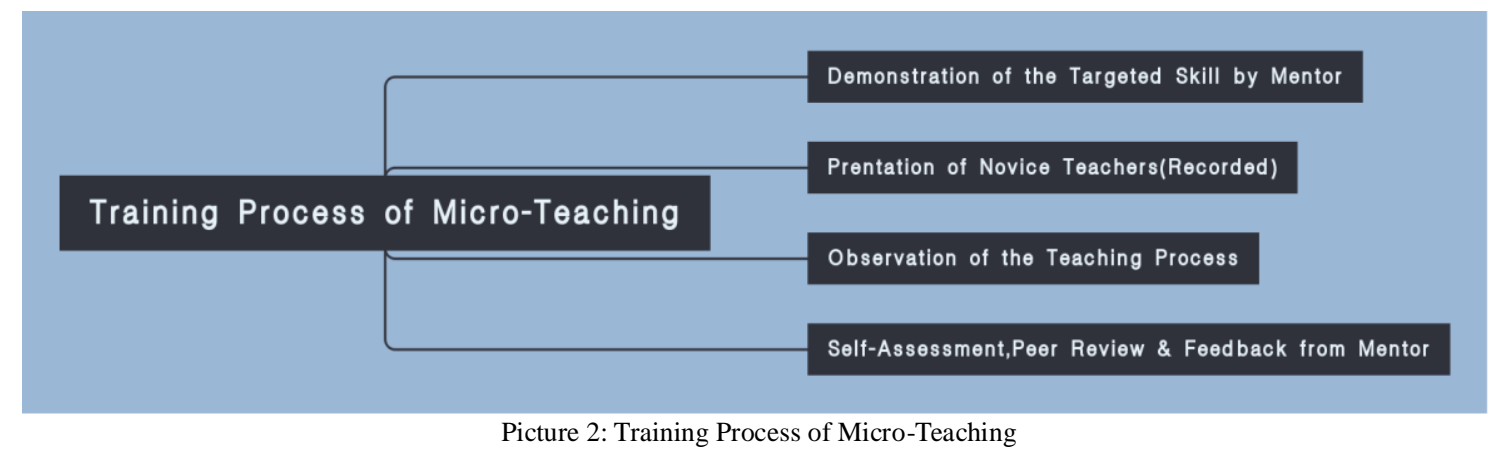

Novice teachers who have never received any relevant training have made improvement in their teaching skills by participating in this programme. From the presentation of targeted teaching skills by novice teachers and their formative assessment profile in this programme, we can safely come to the conclusion that micro-teaching is effective in terms of preparing novice teachers for the future teaching.

\section{An ANAlysis of the DEVElopMent OF NOVICE TEACHERS}

\section{A. The Formative Assessment from Novice Teachers}

Before the implementation of the program, the formative assessment forms (see appendix)have been distributed to novice teachers. From the questionnaires collected, $95 \%$ of the novice teachers do not have much confidence in their teaching. "I have no idea what a class should be like since I do not graduate from a normal university. " Most of the novice English language teachers at high school used to be English majors and have not received any relevant training and it is understandable for them to feel lack of confidence in their teaching positions. Based on their personal experience as students before, $80 \%$ of them reckon the presenting skills is more important than other skills, such as lead-in, questioning, and reinforcing etc. It is probably because lecturing plays a vital role in the process of teaching. The skills of question-proposing and reinforcement are another two important skills that novice teachers find challenging. It is probably because these two teaching behaviors are impulsive and novice teachers do not have enough experience to deal with the unprepared situations in class. The concluding part of a lesson is also quite difficult for novice teachers: they usually wrap up the class in a hurry because when the session ends they still have a lot to explain and elaborate on. Results from the questionnaire provide us with more information concerning the implementation of the micro-teaching program.

Assessment has been regarded as a useful tool to evaluate students' performance and the quality of learning outcomes usually are dependant of assessment. Generally, there are two types of assessment: summative assessment and formative assessment. Formative assessment is more compatible for our program because it can provide novice teachers with feedback on progress and development. The formative assessment (see appendix)in this research is an ongoing process: novice teachers receive feedback from their peers; make constructive changes accordingly afterwards; re-present their teaching and have it recorded again. Formative assessment for the micro-teaching program is beneficial in the following aspects: First, formative assessment encourages critical thinking. Assessment should not only confine itself to what will be assessed in the end of the training, but rise above it by embracing more activities that foster openness of innovative ideas towards the development of deep learning. The best way of learning is teaching. Novice teachers have to be critical and reflective on their teaching. Second, formative assessment helps to maintain motivation and self-esteem of novice teachers. Feedback from peers can influence novice teachers' motivation and sense of achievement. In the formative assessment form, we intend to encourage, rather than discourage them from improving their teaching skills. Third, formative assessment is used to develop novice teachers' ability to reflect, self-assess and self-correct. Novice teachers are assumed to occupy an active role in the assessment of their teaching. They are involved in assessing their own teaching against criteria, explore self- and peer-evaluation in different contexts (see appendix). Fourth, formative assessment for novice teachers can be more objective and constructive. Compared to the traditional observation method, the feedback from the experienced teachers is usually delayed. In this micro-teaching program, novice teachers can get feedback from the peers directly. Feedback is immediate and connected with novice teachers' understandings of what is expected of them. Feedback of quality should be frequent and of use. The formative assessment implemented in this program is an on-going evaluation for all the sessions, which can help novice teachers improve their teachings skills relevant to their future work. Feedback should not be perceived as a tool to punctuate assessment, rather than an on-going evaluation that is provided continuously. It needs to be received by novice teachers while feedback still matters to them and in time for them to pay attention to further acquisition of teaching skills. Fifth, the formative 
assessment in this program is more engaging than the traditional one. Feedback should be perceived as a dialogue rather than as information transmission, if the feedback should be effective and the information provided is understood. Novice teachers not only receive initial feedback information but also have the opportunity to engage the supervisor and peers in the discussion about the feedback.

After having received a two-month sessions of micro-teaching training, teacher A reflects on his performances and the progresses he has made in the formative assessment:

"I graduated as an English major and I had not a clue about how to be a teacher. What are teaching skills? What should be an effective lesson like? Can the information be conveyed to the target audience? What is the layout of a class? --All these questions perplexed me for quite a while. Some experienced teachers came to observe my class and they gave me a lot of suggestions based on their teaching experiences. I was still quite confused about my teaching and also felt not so confident in teaching. After the training of micro-teaching, now I know what type of teaching skills I should apply in class. The feedback from my students reveals that too--my class is more lively and engaging than before. I think now I am on the right track and start to enjoy being a teacher. "

Teacher B reflected on her performance and said:

"Micro-teaching helped me to observe and analyze my own teaching, offering me a brand-new opportunity to reflect on my teaching manner. I have been a part-time teacher for several years but I have never been trained systematically as to how to be a teacher. The teaching skills involved in the micro-teaching program are useful and beneficial for my teaching. I will apply the skills I have acquired in this program in my teaching routine."

B. The Comparative Analysis of the Teaching Materials

\begin{tabular}{|c|c|}
\hline Before the Training & After the Training \\
\hline $\begin{array}{l}\text { 疑问副词 how 用来询问天气。 } \\
\text { 今天天气怎么样? How's the weather too } \\
\text { 【拓展】询问天气还可以说: } \\
\text { What's the weather like today? } \\
\text { 某地天气怎么样? How's the weather int地) }\end{array}$ & $\begin{array}{l}\text { Weather Report } \\
\text { Good morning/afternoon, ladies and } \\
\text { gentlemen! } \\
\text { Here is the weather report! } \\
\text { It's ...in Toronto. } \\
\text { Boston is.... } \\
\text { Thanks for } \\
\text { listening and } \\
\text { have a good } \\
\text { day! }\end{array}$ \\
\hline $\begin{array}{l}\text { = What's the weather like int地方? } \\
\text { 表示天气如何: } \\
\qquad \text { It's+表示天气的形容词或动词ing }\end{array}$ & $\begin{array}{l}\text { Summary: A: How's the weather? } \\
=\text { What's the weather like? } \\
\text { B: It's cloudy }\end{array}$ \\
\hline
\end{tabular}

Picture 3: Teaching Materials by Novice Teacher A 


\begin{tabular}{|c|c|}
\hline Before the Training & After the Training \\
\hline $\begin{array}{l}\text { - Love our family, because it creates us. } \\
\text { - Learn to communicate, because it's part o } \\
\text { growing up. }\end{array}$ & $\begin{array}{l}\text { 3CS (Alice's suggestions) } \\
\text { •Complain } \\
\cdot \text { C ommunicate } \\
\cdot{ }^{\prime} \text { 'ompromise (妥协) } \\
\text { •C hange }\end{array}$ \\
\hline
\end{tabular}

Two novice teachers were selected: teacher A is male and he is responsible for the English language teaching for junior high school students; teacher B is female and she is in charge of the English language teaching for senior high school students.

The teaching materials from teacher A are concerning the lead-in section. Before the training, teacher A used complicated sentences to convey information to students: the layout of the Powerpoint slide (as shown in Picture 3)is not pleasing and too many Chinese equivalents are involved. After the training, teacher A uses pictures to visualize the information conveyed and the situational teaching method is applied which can be very useful to aid students' receiving and comprehension of the information. Before the micro-teaching, teacher A is not aware of the lead-in skills. In the teaching material he presenting, we can notice his lack of relevant skills in giving an appropriate lead-in skill as he put too much information which seems to be uninteresting to high school students. He used the "top-down" style, conveying the grammatical rules to learners, via the summary of the grammatical points in both English and Chinese. Learners usually find this slide not attractive and the "top-down" style is not engaging enough. After the training, teacher A knew how to apply certain lead-in skills to involve students in the learning process: he used less words but more visual aids which are very useful, especially for visual learners. Mind mapping and the style of weather forecast provide an abundance of information closely related to the topic of the lesson which enables learners to acquire the vocabulary and the relevant grammatical points.

The teaching materials from teacher B are for the concluding part. Before the training, she used lengthy sentences to conclude the teaching. After the training, she used simple and short words to summarize the lesson which leaves a deep impression on the students. The concluding part is also of great importance. In this part, teachers usually sum up the main ideas of the lesson, evaluate learners' performance, and assign tasks for students to do outside class. The concluding session on the right(see Picture 4) made by teacher B is obviously more simple and concise than before, but still left not enough time to learners to reflect on what they have acquired and she was not well aware of the fact whether the learners have a good command of the language skills involved. Also, the assignment was not stated clearly which might be quite confusing for high school students. Teacher B has an impeccable pronunciation and she used to be working as a part-time English teacher; but her teaching skills have room for improvement. After the micro-teaching training, she has been keenly aware of the teaching process and the teaching skills involved in a class. Now when she is designing activities in class, she takes teaching objectives and teaching skills into consideration and her class is more effective than before.

\section{CONCLUSION}

The micro-teaching program in this research has yielded positive results. Most of the young English teachers at high-school graduated as English majors; very often, they do not receive any professional training concerning the know-how of teaching before they start their career as a teacher. Compared to the traditional manner of teacher-training program, the micro-teaching program has three advantages: First, it makes the teacher training more objective and more emphasis has been laid upon learners. The behaviors of both the teacher and the students are all captured by the well-equipped micro-teaching laboratory, and we can examine and analyze the video clips of teaching. In this manner, novice teachers can reflect on their teaching in an innovative style which they have never experienced before. Lead-in skills, presentation skills, question-proposing skills, feedback and reinforcement etc., all these indispensable parts of teaching have been diversified and analyzed. Second, the halo effect of experienced teachers has been minimized. Novice teachers can learn from the seniors in a more objective way. Third, the video-clips can be used as materials for research: the coexistence of teaching and researching endows novice teachers with a brand-new platform for their self-development in this life-long career.

This micro-teaching program can give participating teachers the time and space to reflect on their school-based practice through collaboration with their colleagues, address some of the limitations of school-based training and can 
build up their confidence in their teaching. Feedback supports the findings that novice teachers feel this program can help them to develop their teaching skills and they begin to perceive teaching through the lens of students. It can help to restructure their initial views about the role of the teacher and what learning looks like.

Micro-teaching has great potential to be unleashed. Novice teachers, for the first time, reflect on their teaching in a more objective style. All the details of their teaching have been attended to, and the feedback they receive is more effective and beneficial for their teaching work. Novice teacher adopt a brand-new perspective towards teaching and learning and their confidence in teaching starts to build up. This research has been conducted during a period of three months, and more longitudinal research is needed into the positive effects of the implementation of micro-teaching for novice English teachers at high school. This program is not only suitable for novice teachers, but also experienced teachers who are seeking for solutions to their challenges in their daily teaching routine. If this program can be implemented on a regular basis with more teachers participating in, being novice or experienced, the teaching quality of the school will be improved and teachers will feel more satisfied with teaching experience.

Micro-teaching program can function as a platform for teachers to improve their teaching skills in an objective style and provide solutions to their problems occurring in teaching. Micro-teaching would serve to satisfy the requirements for educating high-school English teachers in the Chinese context while enabling them to be more informed, curious, and critical in their teaching and researching.

\section{ApPendix. The Training Profile For Novice Teachers}

\begin{tabular}{|l|l|}
\hline Basic information & \\
$\begin{array}{l}\text { Self-evaluation before attending this } \\
\text { program }\end{array}$ & \\
\hline The most challenging part of teaching & \\
\hline $\begin{array}{l}\text { The most important guidance and } \\
\text { suggestion from mentor }\end{array}$ & \\
\hline
\end{tabular}

\section{The schedule of the program}

\begin{tabular}{|l|l|l|l|}
\hline time & skills & notes \\
\hline 1 & $\begin{array}{l}\text { Lead-in skills \& language used within } \\
\text { the classroom }\end{array}$ & \multicolumn{2}{l|}{} \\
\hline 2 & Displaying and proposing questions & & \\
\hline 3 & Feedback and reinforcement & & \\
\hline 4 & $\begin{array}{l}\text { Organization of the class and the } \\
\text { concluding part }\end{array}$ & & \multicolumn{2}{l|}{} \\
\hline
\end{tabular}

3. Teaching materials used by novice teachers

(teaching plan, Powerpoint and some other relevant materials) 
4. Reflection on teaching by novice teachers

【Notes of discussion in class】

【Notes of presentation】

【Reflection of mentor's presentation】

【Reflection of teaching 】

5. Assessment of teaching

【Comments from students】

【Comments from peer teachers】

【Comments from mentors】

\section{ACKNOWLEDGEMENTS}

I feel grateful for WU Daogang and ZHANG Li, who have contributed their teaching materials to this research.

\section{REFERENCES}

[1] Allen, D.W. \& Eve, A.W. (1968). Microteaching, Theory into Practice, 7(5): 181-185.

[2] Arsal, Z. (2014). Microteaching and pre-service teachers' sense of self-efficacy in teaching, European Journal of Teacher Education, 37(4):453-464.

[3] Bell, N.D. (2007). Microteaching: what is it that is going on here?, Linguistics and Education, 18(1): 24-40.

[4] Carver, D., \& Wallace, M. J. (1975). Some applications of micro-teaching to TESL. English Language Teaching Journal, 29(3), 184-190. Retrieved from https://search.proquest.com/docview/57963672?accountid=11232 Accessed on 24/11/2019.

[5] Cousin, W. D., Carver, D. J., Dodgson, C. F., \& Petrie, J. K. F. (1978). Prescriptive categories in micro-teaching in a pre-service TEFL programme. Sstem, 6(2), 98-105. Retrieved from https://search.proquest.com/docview/85439269?accountid=11232 Accessed on 24/11/2019.

[6] Donnelly, R. \& Fitzmaurice, M. (2011). Towards productive reflective practice in microteaching, Innovations in Education and Teaching International, 48(3):335-346.

[7] Fan, J.Z. \& Gao, H.X. (2010). A Course on Micro-teaching. Beijing: Beijing Normal University Press (in Chinese).

[8] Fisher, D., \& Frey, N. (2019). The micro-teaching advantage. Educational Leadership, 76(5), 82. Retrieved from https://search.proquest.com/docview/2196497873?accountid=11232 Accessed on 24/11/2019.

[9] Griffiths, J. (2016). Bridging the school placement gap with peer micro-teaching lesson study. International Journal for Lesson and Learning Studies, 5(3), 227-238. doi:http://dx.doi.org/10.1108/JLLS-11-2015-0035 Accessed on 24/11/2019.

[10] Kablan, Z. (2012). The effect of experiential-learning model oriented micro teaching practices on pre-service teachers' skills. Egitim Ve Bilim, 37163), 239-n/a. Retrieved from https://search.proquest.com/docview/1009842184?accountid=11232 Accessed on 24/11/2019.

[11] Lee, G. C., \& Cheng-Chih, W. (2006). Enhancing the teaching experience of pre-service teachers through the use of videos in web-based computer-mediated communication (CMC): Journal of the association for programmed learning ETTI. Innovations in Education and Teaching International, 43(4), 369-380. Retrieved from https://search.proquest.com/docview/210671041 ?accountid=11232 Accessed on 24/11/2019.

[12] Li, J. (2012). Guidance and Training of Teaching Skills for English Language Teaching. Nanjing: Nanjing University Press(in Chinese).

[13] Li, S. (2009). A Course on Teaching Skills Training for Professional Teachers. Beijing: Higher Education Press (in Chinese).

[14] Liu,L.\& An, Y.J. (2005). Diversified structure of micro-teaching. Tele-education Research, 149(9): 55-59 (in Chinese).

[15] Merghler, A.G. \& Tangen, D. (2010). Using microteaching to enhance teacher efficacy in per-service teachers, Teaching Education, 21(2): 199-210.

[16] Phillips, E. T. J. (1975). Micro-teaching: A tool of in-service training. English Language Teaching Journal, 29(2), $120-129$. Retrieved from https://search.proquest.com/docview/57928112?accountid=11232 Accessed on 24/11/2019.

[17] Sachs, G. T. (1999). Preservice teacher development through a more dynamic approach to micro-teaching. Perspectives: Working Papers in English and Communication, 11(1), 119-145. Retrieved from https://search.proquest.com/docview/85706870?accountid=11232 Accessed on 24/11/2019.

[18] Tian, H.W. (2003). Explore Micro-teaching, Enhance Teacher-training. Tele-education Research, 123(7):52-54,57(in Chinese).

[19] Yogi, M. (2013). Developing language and teaching skills through videoconferencing and collaborative projects: a case study of English teacher training programs in Japan., International Journal of Arts \& Sciences, 6(4), 347-362. Retrieved from https://search.proquest.com/docview/1496696625?accountid=11232 Accessed on 24/11/2019. 
Jing Shi is currently a PhD student at the University of Macau, and she holds a master degree from the University of Warwick, the UK. She is an associate professor in the School of English for International Business, Guangdong University of Foreign Studies, Guangzhou, China. Her research interests include micro-teaching and teacher development; language intervention; corpus linguistics etc. 